\title{
KESIAPSIAGAAN MASYARAKAT DALAM MENGHADAPI BENCANA KEBAKARAN DI KOTA BANJARMASIN (Community Preparedness to Prevent Fire Disaster in the City of Banjarmasin)
}

\author{
Dyah Trifianingsih $^{1}$, Dwi Martha Agustina², Elisa Tara ${ }^{3}$ \\ 1) 2) 3) Sarjana Keperawatan, STIKES Suaka Insan Banjarmasin \\ Email: dya3vee@yahoo.com
}

\begin{abstract}
Fire disasters are accompanied with devastating impact affecting both lives and properties. The magnitude of the impacts has been severe in places with low levels of fire disaster preparedness. Disaster preparedness is one of the important elements in disaster risk reduction and it encompasses community awareness, readiness to render appropriate responses and quick recovery. The community has a role in reducing the risk of a fire disaster. Communities need to strengthen and increase capacity in disaster preparedness at the local and community level. The aim of this study was to empower the community in this case the fire disaster preparedness. This type of research was quantitative with a descriptive research design. A sample of 74 families in Pekauman Village, RT.09 RW.01, was taken by total sampling. The research instrument used was a questionnaire, and data analysis used was a frequency distribution. This study showed that most respondents in the very ready category as many as 44 (59.5\%), and at least 7 (9.5\%) were in the almost ready category. Community empowerment can prevent disasters and increases the level of preparedness in case of fire occurrence.
\end{abstract}

Keywords: community, fire disaster, preparedness

\begin{abstract}
ABSTRAK
Bencana kebakaran memberikan dampak yang mempengaruhi kehidupan dan harta benda. Besarnya dampak semakin parah di tempat-tempat dengan tingkat kesiapsiagaan bencana kebakaran yang rendah. Kesiapsiagaan bencana salah satu elemen penting dalam pengurangan risiko bencana dan meliputi kesadaran masyarakat, kesiapan memberikan tanggapan yang tepat dan pemulihan yang cepat. Masyarakat memiliki peran dalam mengurangi resiko kebencanaan kebakaran. Komunitas dan masyarakat perlu memperkuat dan meningkatkan kemampuan dalam kesiapsiagaan bencana pada daerah dan tingkat komunitasnya. Tujuan penelitian ini untuk mengetahui kesiapsiagaan masyarakat di Kelurahan Pekauman Banjarmasin dalam menghadapi bencana kebakaran. Penelitian ini menggunakan rancangan deskriptif kuantitatif. Penggumpulan data menggunakan kuesioner. Sampel sebanyak 74 kepala keluarga di Kelurahan Pekauman RT.09 RW.01 yang diambil dengan total sampling. Analisa data menggunakan distribusi frekuensi. Dari hasil penelitian diperoleh kesiapsiagaan masyarakat dalam menghadapi kebakaran mayoritas berada dalam kategori sangat siap sebanyak $44(59,5 \%)$, dan paling sedikit berada di kategori hamper siap sebanyak $7(9,5 \%)$. Pemberdayaan masyarakat dapat mencegah terjadinya bencana dan meningkatkan kesiapsiagaan jika terjadi kebakaran.
\end{abstract}

Kata kunci: kebakaran, kesiapsiagaan, komunitas.

\section{PENDAHULUAN}

Kasus kebakaran merupakan salah satu bentuk kecelakaan yang memerlukan perhatian khusus dan memerlukan pencegahan (upaya preventif) untuk mengurangi bahkan menghilangkan kemungkinan terjadinya kebakaran. Salah satunya bisa dengan manajemen risiko, karena sangat penting bagi kelangsungan suatu usaha atau kegiatan jika terjadi bencana seperti kebakaran (Kuntoro, 2017).

Kejadian kebakaran mengakibatkan dampak yang besar bagi masyarakat. Selain kerugian material, akibat yang lebih fatal berupa hilangnya nyawa orang, dapat terjadi akibat kebakaran. Risiko kebakaran di perkotaan terbentuk oleh adanya ancaman berupa potensi api yang sewaktu-waktu 
dapat menjadi sumber kebakaran, seperti penggunaan listrik dan kompor gas, serta kerentanan masyarakat tinggi, yang dipengaruhi kepadatan penduduk dan bangunan. Risiko bencana kebakaran di kawasan perkotaan tersebut susah diminimalkan, terlebih menyangkut kebutuhan pokok masyarakat akan listrik dan memasak. Bagitu pula dengan pengurangan kepadatan penduduk untuk mengurangi kerentanan.

Upaya yang dapat dilakukan adalah dengan penanggulangan bencana melalui tindakan kesiapsiagaan terhadap bencana tersebut. Upaya peningkatan kesiapsiagaan dapat meminimalkan kerugian yang muncul jika bencana terjadi. Kesiapsiagaan merupakan salah satu fase dalam pengelolaan bencana, yang tertuang dalam UU Nomor 24 tahun 2007 tentang penanggulangan bencana. Masyarakat sebagai elemen utama yang merasakan suatu bencana harus mempunyai kemandirian dalam menghadapi bencana, sebab kerugian yang ditimbulkan oleh suatu bencana sangat ditentukan oleh kesiapan, pengetahuan dan keterampilan yang dimiliki masyarakat. Indikator yang digunakan untuk menilai kesiapsiagaan masyarakat dalam bencana berdasarkan LIPI-UNESCO/ISDR (2006) antara lain pengetahuan, sikap kesiapsiagaan, rencana tanggap darurat, system peringatan dini, dan mobilitas sumber daya.

Beberapa penelitian di Indonesia menunjukan masih lemahnya upaya kesiapsiagaan dan penanganan darurat untuk menghadapi bencana secara mandiri dan proaktif. Hal ini tergambar dari studi kesiapsiagaan warga dalam menghadapi bencana di beberapa daerah dengan menilai indeks kesiapsiagaan dilihat dari sisi individu dan keluarga, komunitas sekolah dan pemerintah yang masih rendah dengan kategori kurang siap (Nugroho, 2015).

World Fire Statistic Report (NFPA) menyatakan bahwa 7-8 juta jiwa di dunia dilaporkan pernah mengalami kejadian kebakaran dan 5-8 juta jiwa mengalami kecelakaan akibat kebakaran. Pada tahun 2015, di Amerika Serikat dilaporkan sejumlah 1.345.500 kasus kebakaran yang menyebabkan 3.280 orang meninggal, 15.700 orang cedera dan menimbulkan kerugian material (NFPA, 2018). Kebakaran pemukiman adalah salah satu contoh bencana non alam yang sering terjadi di Indonesia khususnya di kota-kota padat penduduk seperti Jakarta, Surabaya, Surakarta, dan Semarang. Mengingat saat ini jumlah penduduk Indonesia tahun 2015 mencapai lebih dari 267 juta jiwa, dampak yang terjadi karena kebakaran berupa kematian, kecacatan, kerugian finansial, maupun korban jiwa. Sehingga, kebutuhan akan tempat tinggal juga semakin tinggi, terutama di kota-kota besar kepadatan penduduk dipengaruhi oleh laju pertumbuhan penduduk yang tinggi sebagai akibat meningkatnya kebutuhan lahan pemukiman di perkotaan (Aprilia, 2014).

Data Badan Nasional Penanggulangan Bencana (BNPB) melaporkan kejadian bencana pada 2016 dan 2017 secara berturut-turut adalah 2.306 kejadian dan 2.392 kejadian. Sutopo 2018 dalam (Farisa, 2018) menulis bahwa BNPB sudah mencatat 1.999 kejadian bencana hingga Oktober 2018 di Indonesia, akan tetapi pertambahan jumlah pemukiman yang begitu besar tidak di iringi dengan sarana dan prasarana yang menunjang keselamatan bersama setiap bangunan. Sehingga ancaman terjadi suatu bencana kebakaran bangunan juga semakin besar.

Bencana yang sering terjadi di Kalimantan Selatan yaitu kebakaran hutan, lahan serta kebakaran rumah/penduduk. Tahun 2019 pada dua bulan terakhir yaitu bulan AgustusSeptember wilayah Kota Banjarmasin ada 13 kejadian kebakaran rumah/pemukiman dengan korban menderita 685 jiwa (BNPB, 2019). Setidaknya ada 45 kasus kebakaran yang terjadi sejak mei 2021 terjadi di Kota Banjarmasin, Kalimantan Selatan. Kepala bidang pemadam kebakaran Kota Banjarmasin, Said Abdurrahman merinci, di bulan Januari sudah terjadi 5 kali kebakaran, Februari 6 kali, Maret 8 kali dan bulan April 13 kali. Faktor utama kebakaran di Banjarmasin karena kelalaian manusia dan juga ada yang diakibatkan korsleting. Dari sekitar 45 kasus tersebut, kebakaran banyak terjadi pada rumah semi permanen. Api dengan cepat membesar dan sulit dikendalikan petugas. Data total korban meninggal dunia akibat kebakaran di Banjarmasin selama 2021 berjumlah 2 orang, selain itu kebakaran menyebabkan kerugian ditaksir hingga milyaran rupiah (Haswar, 2021).

Kelurahan Pekauman, Kecamatan Banjarmasin Selatan, Kota Banjarmasin merupakan salah satu dari 12 kelurahan yang ada di kecamatan Banjarmasin Selatan dimana salah satu kawasan yang sering dilanda kebakaran di Kota Banjarmasin. Sejarah mencatat musibah kebakaran terbesar sepanjang zaman terjadi pada tahun 1973 di kelurahan Pekauman, Kota Banjarmasin. Kondisi pemukiman yang padat didukung suhu yang tinggi, serta penggunaan kayu sebagai material utama bangunan menyebabkan api cepat merambat bila terjadi kebakaran. Pemukiman pada kelurahan Pekauman merupakan pemukiman padat dengan riwayat kebakaran tinggi di Banjarmasin. Untuk menghindari tingginya bencana kebakaran, tidak bisa hanya dilakukan upaya mitigatif seperti dibentuknya banyak BPK, namun dibutuhkan upaya preventif salah satunya dengan pemberdayaan masyarakat melalui peningkatan pengetahuan mulai dari kesiapsiagaan evakuasi, dan pengambilan keputusan evakuasi dan penanggulangan kebakaran sehingga masyarakat lebih baik dalam kesiapsiagaan mengahadapi bencana kebakaran.

\section{METODE}

Jenis penelitian ini merupakan penelitian kuantitatif dengan desain penelitian deskriptif. Penelitian ini dilakukan di Kelurahan Pekauman Banjarmasin. 
Populasi dalam penelitian ini adalah kepala keluarga yang tinggal di Kelurahan Pekauman RT.09 RW.01 Banjarmasin. Sampel dalam penelitian ini berjumlah 74 responden yang diambil dengan tehnik total sampling. Instrumen yang digunakan dalam penelitian ini untuk mendapatkan gambaran kesiapsiagaan masyarakat adalah kuesioner. Kuesioner terdiri dari 25 item pertanyaan yang mencakup kesiapsiagaan masyarakat menghadapi bencana kebakaran, meliputi pengetahuan, sikap kesiapsiagaan, rencana tanggap darurat, system peringatan, mobilisasi sumber daya. Hasil realibilitas menunjukan hasil uji Kuder-Richardson 20 (KR20) sebesar 0,906 dapat disimpulkan alat ukur yang peneliti gunakan dapat diandalkan.

\section{HASIL}

\section{Karakteristik Responden}

Karakteristik Responden Penelitian berdasarkan jenis kelamin, tingkat pendidikan dan usia dapat dilihat pada tabel 1. di bawah ini:

Tabel 1. Distribusi Frekuensi Responden Penelitian berdasarkan Jenis Kelamin, Tingkat Pendidikan dan Usia

\begin{tabular}{lllll}
\hline No & Karakteristik & Katagori & $\boldsymbol{f}$ & \% \\
\hline 1 & Jenis Kelamin & Laki-laki & 64 & 85,3 \\
& & Perempuan & 10 & 13,3 \\
& & Jumlah & 74 & 100,0 \\
\hline 2 & Tingkat & SD & 2 & 2,7 \\
& Pendidikan & SMP & 10 & 13,5 \\
& & SMA & 52 & 70,3 \\
& & Perguruan Tinggi & 10 & 13,5 \\
& & Jumlah & 74 & 100,0 \\
\hline 3 & Usia & $17-25$ & 4 & 5,4 \\
& & $26-36$ & 35 & 47,3 \\
& & $36-45$ & 26 & 35,1 \\
& & $46-55$ & 9 & 12,2 \\
& & Jumlah & 74 & 100,0 \\
\hline
\end{tabular}

Tabel 1 menunjukkan bahwa mayoritas responden adalah berjenis kelamin laki-laki $(64 ; 85.3 \%)$, memiliki tingkat pendidikan tertinggi adalah SMA $(52 ; 70.3 \%)$ dan berusia 26-36 (35; 47.3\%).

Masyarakat sebagai elemen utama dalam kesiapsiagaan harus memiliki pengetahuan dan kesiapan dalam menghadapi suatu bencana, banyaknya korban jiwa akibat suatu bencana diakibatkan oleh kurangnya kesadaran dan kesiapsiagaan dari masyarakat sendiri, sehingga masyarakat memiliki peranan penting atau ikut berperan dalam upaya pengoptimalisasi dan mengurangi resiko bencana.

\section{Kesiapsiagaan masyarakat dalam menghadapi bencana kebakaran}

Selanjutnya, gambaran Kesiapsiagaan masyarakat dalam menghadapi bencana kebakaran dapat dilihat pada tabel berikut ini:

Tabel 2. Distribusi frekuensi kesiapsiagaan masyarakat menghadapi bencana kebakaran

\begin{tabular}{lllll}
\hline No & Karakteristik & Katagori & $\boldsymbol{f}$ & \% \\
\hline 1 & Kesiapsiagaan & Sangat Siap & 44 & 59,5 \\
& & Siap & 23 & 31,1 \\
& & Hampir Siap & 7 & 9,5 \\
& & Jumlah & 74 & 100,0 \\
\hline
\end{tabular}

Tabel 2 di atas menunjukkan sebagian besar responden yaitu sebanyak $44(59,5 \%)$ memiliki kesiapsiagaan dengan kategori sangat siap dan paling sedikit responden dalam kategori hampir siap sebanyak 7 (9,5\%). Hal ini dapat dilihat dari hasil jawaban dari kuesioner yang telah diberikan kepada responden dimana masyoritas responden telah memiliki pengetahuan mengenai bencana kebakaran yang baik meliputi pemahaman mengenai tindakan penyelamatan diri yang tepat saat terjadi kebakaran serta tindakan dan peralatan yang perlu disiapkan sebelum terjadi kebakaran, ancaman bencana kebakaran yang merupakan ancaman akibat kondisi pemukiman yang padat penduduk dan mayoritas penggunaan kayu sebagai material utama bangunan menyebabkan api cepat merambat bila terjadi kebakaran. Suatu bangunan memiliki potensi terjadinya kebakaran apabila bangunan tersebut material konstruksinya berasal dari material yang mudah terbakar.

\section{PEMBAHASAN}

Pengetahuan merupakan salah satu faktor yang ada dalam kesiapsiagaan masyarakat dalam menghadapi bencana, pengetahuan menjadi aspek dasar untuk kesiapsiagaan yang harus dimiliki oleh setiap masyarakat, agar dapat memberikan informasi kepada anggota keluarga bila suatu saat terjadi bencana. Pengetahuan yang dimiliki masyakarat biasanya dapat mempengaruhi sikap dan kepedulian keluarga untuk siap dan siaga dalam mengantisipasi terjadinya bencana, terutama bagi mereka yang bertempat tinggal di daerah yang rentan terhadap bencana alam (Dantzler, 2013). Indikator pengetahuan dan sikap individu/ masyarakat merupakan pengetahuan dasar yang semestinya dimiliki oleh individu meliputi pengetahuan tentang bencana, penyebab dan gejala-gejala, maupun apa yang harus dilakukan bila terjadi bencana kebakaran terjadi.

Masyarakat yang memiliki pengetahuan yang lebih baik terkait dengan bencana yang terjadi cenderung memiliki kesiapsiagaan yang lebih baik dibanding masyarakat yang 
minim memiliki pengetahuan. Masyarakat yang memiliki pengetahuan yang baik tentang penanggulangan kebakaran dalam sikap kesiapsiagaan akan memiliki upaya pencegahan penanggulangan kebakaran yang baik pula (Pahriannoor, 2020). Hasil penelitian Thomas (2015), menyampaikan bahwa pengetahuan responden mengenai bencana berhubungan dengan tingkat kesiapannya menghadapi bencana. Hal ini sesuai dengan penelitian Chan (2012) yang menunjukan bahwa pengaruh paling besar dalam perhitungan tingkat kesiapsiagaan keluarga pedesaan dengan tingkat pengetahuan yang baik meningkatkan indeks kesiapsiagaan keluarga.

Kesiapsiagaan masyarakat menghadapi kebakaran dikelompokan menjadi beberapa parameter, salah satunya adalah sikap. Parameter sikap masyarakat tiap individu/ rumah tangga merupakan gambaran antisipasi yang perlu dilakukan bila kebakaran terjadi. Sikap dalam keluarga juga menjadi salah satu faktor yang mempengaruhi masyakarat dalam mempersiapkan diri dalam kegiatan kesiapsiagaan bencana. Ada dua komponen dari faktor sikap dalam keluarga, pertama melibatkan persepsi risiko, kedua melibatkan pengalaman bencana yang terjadi sebelumnya. Apabila pengetahuan masyarakat akan kesiapsiagaan bencana kebakaran baik dari segi bahaya, kerentanan, risiko dan kegiatan-kegiatan pengurangan risiko cukup memadai maka akan dapat menciptakan aksi masyarakat yang efektif (baik secara sendiri maupun bekerjasama dengan para pemangku kepentingan lainnya) dalam menghadapi bencana. Keluarga yang siap bencana dapat membantu meningkatkan sumber daya komunitas dengan mempersiapkan keluarga yang mandiri (Baker, 2012). Sikap kesiapsiagaan menghadapi kebakaran masyarakat Pekauman selama ini ditunjukan dengan mengikuti perintah petugas pemadam kebakaran dan mengevakuasi diri saat terjadi kebakaran, selalu mengingatkan anggota keluarga untuk mengecek instalasi listrik (kabel), kompor gas ataupun alat elektronik agar terhindar dari bencana kebakaran. Mayoritas masyarakat belum tersedia alat pemadam api ringan/ APAR di rumah mereka. Pengalaman kejadian kebakaran yang terjadi sebelumnya mendorong masyakarat dalam sikap kesiapsiagaan pentingnya mengecek keamanan instalasi listrik, barang-barang elektronik maupun kompor gas di rumah.

Sikap kesiapsiagaan merupakan tindakan-tindakan yang dilakukan untuk mengurangi resiko bencana. Sikap menentukan bagaimana individu dan rumah tangga membuat respon atau bereaksi terhadap suatu situasi bencana. Sikap yang baik terbentuk dan dipengaruhi oleh pengetahuan. Tujuan pentingnya pendidikan kebencanaan adalah menanamkan sikap tanggap dan responsif terhadap bencana sehingga resiko yang fatal bisa dihindari dan diharapkan masyarakat tidak hanya sekedar mengetahui dan memahami konsep bencana, tetapi yang paling penting dan utama adalah bagaimana mereka menghadapi resiko bencana dengan siap- siaga sehingga mampu menimalkan dampak yang lebih parah dari bencana kebakaran.

Masyarakat memiliki peran dalam mengurangi resiko kebencanaan kebakaran. Komunitas dan masyarakat perlu memperkuat dan meningkatkan kemampuan dalam kesiapsiagaan bencana pada daerah dan tingkat komunitasnya. Salah satu indikator kesiapsiagaan adalah bagaimana sistem peringatan dini yang ada di masyarakat, terutama di daerah yang memiliki kerentanan bencana kebakaran. Sistem peringatan meliputi tanda peringatan dan distribusi informasi jika terjadi suatu bencana (Gowing, 2017). Melalui peringatan bencana ini, masyarakat dapat melakukan tindakan yang tepat untuk mengurangi korban jiwa, harta benda dan kerusakan lingkungan. Masyarakat di wilayah Pekauman Banjarmasin telah tersedia sumber informasi untuk peringatan bencana kebakaran, menentukan jalur evakuasi atau titik kumpul saat terjadi kebakaran. Titik kumpul menjadi salah satu elemen yang penting dalam pengelolaan bencana, penentuan titik kumpul untuk evaluasi perlu ditetapkan sebagai langkah kesiapsiagaan. Selama ini masyarakat Pekauman sudah dengan sangat mudah mendapatkan informasi kebakaran baik itu didapat dari pemerintah maupun sosial media.

Hasil penelitian Yulia (2020) menunjukkan bahwa masyarakat memiliki keinginan untuk menjaga keamanan rumahnya dari bencana kebakaran. Masyarakat harus meiliki kesadaran untuk menyusun rencana keamanan, memiliki kepedulian untuk saling berbagi informasi, dan memiliki kepedulian lingkungan akan resiko terjadi kebakaran.

\section{KESIMPULAN}

Hasil penelitian kesiapsiagaan masyarakat Kelurahan Pekauman RT.09 RW.01 Banjarmasin dalam menghadapi bencana kebakaran menunjukkan bahwa mayoritas responden dalam kategori sangat siap sebanyak $44(59,5 \%)$ dan paling sedikit berada dalam kategori hampir siap sebanyak $7(9,5 \%)$.

Hasil penelitian ini diharapkan sebagai tambahan informasi dan pertimbangan bagi masyarakat Pekauman untuk semakin meningkatkan kesiapsiagaan menghadapi bencana kebakaran dengan meningkatkan pengetahuan, keterampilan dan sikap melalui mengikuti seminar atau pelatihan, simulasi kesiapsiagaan terjadap bencana. Bagi pihak pendidikan terutama pendidikan keperawatan dan profesionak kesehatan dapat melakukan kegiatan pengabdian masyarakat untuk memberikan optimalisasi kesiapsiagaan menghadapi bencana kebakaran.

\section{ACKNOWLEDGEMENT}

Terima kasih kami ucapakan kepada Kepala Satpol PP Bagian Pemadam Kebakaran Kota Banjarmasin, Ketua Kelurahan Pekauman, Seluruh Kepala keluarga di Kelurahan 
Pekauman RT.09 RW.01 Banjarmasin yang telah bersedia dan berperan aktif sebagai responden dalam penelitian ini, STIKES Suaka Insan.

\section{DAFTAR PUSTAKA}

Arismawati, M.D \& Wijaya, O. (2019). Analisis Kesiapsiagaan Masyarakat dalam Menghadapi Bencana Kebakaran Pada Kawasan Pemukiman Padat Penduduk (Studi Kasus Kelurahan Prawirodirjan Yogyakarta). Artikel Kesehatan Masyarakat, Universitas Ahmad Dahlan.

Badan Nasional Penanggulangan Bencana. (2019). Daftar Bencana Informasi Indonesia (Dibi). Jakarta:BNPB

Baker, L. R., \& Cormier, L. A. (2012). Disaster Preparedness and Families of Children with Special Needs: A Geographic Comparison. Journal of Community Health, 38(1), 106-112.

Chan, E. Y. Y., Kim, J. H., Lin, C., Cheung, E. Y. L., \& Lee, P. P. Y. (2012). Is Previous Disaster Experience a Good Predictor for Disaster Preparedness in Extreme Poverty Households in Remote Muslim Minority Based Community in China?. Journal of Immigrant and Minority Health, 16(3), 466-472.

Dantzler, D. (2013). Basic household disaster preparedness decisionalInfluences among male federal employees in the national Capital region. Dissertation Doctor of Philosophy Capella University. ProQuest LLC. UMI Number:3559889.

Farisa, F.C. (2018). BNPB: Selama 2018, Ada 1.999 Kejadian Bencana Kebakaran. Kompas.com. Retrieved 5 November 2020 at 13:20 WITA From Https://Nasional.Kompas.Com/Read/2018/10/25/2257 2321/Bnpb-Selama-2018ada-1999-Kejadian-Bencana

Gowing, J. R., Walker, K. N., Elmer, S. L., \& Cummings, E. A. (2017). Disaster Preparedness among Health Professionals and Support Staff: What is Effective? An Integrative Literature Review. Prehospital and Disaster Medicine, 32(03), 321-328.

Haswar, Andi. M. (2021). Ada 45 Kasus Kebakaran dalam 5 Bulan di Banjarmasin, 2 Orang Meninggal Dunia. Retrieved from https://regional.kompas.com/read/2021/05/20/215702 278/ada-45-kasus-kebakaran-dalam-5-bulan-dibanjarmasin-2-orang-meninggal-dunia.

Hermon, Dedi. (2015). Geografi Bencana Alam. Jakarta

Jaslow, D., Ufberg, J., Yoon, R., McQueen, C., Zecher, D., \& Jakubowski, G. (2005). Fire Safety Knowledge and Practices Among Residents of an Assisted Living Facility. Prehospital and Disaster Medicine, 20(02), 134-138.

Kuntoro, C. (2017). Implementasi Manajemen Risiko Kebakaran Berdasarkan (Is) ISO 31000 PT Apac. Inti Corpora. HIGEIA, 1(4), pp. 109-119
LIPI-UNESCO/ISDR. (2006). Kajian Kesiapsiagaan Masyarakat dalam mengantisipasi Bencana Gempa Bumi dan Tsunami.

Martanto, C., Aji, A., \& Parman, S. (2017). Kajian Kesiapsiagaan Masyarakat dalam menghadapi Bencana Kebakaran di Kelurahan Kembangsari Kecamatan Semarang Tengah. Edu Geography,2

Nakao, R., Kawasaki, R., \& Ohnishi, M. (2019). Disaster preparedness of hillside residential area in Nagasaki city, Japan: evaluations regarding experiences related to a fire. Journal of Rural Medicine, 14(1), 95-102.

National Fire Protection Association (NFPA). (2018). Standar for Portable Fire Extinguisherts. USA

Nugroho. (2015). Preparedness Assessment Tools For Indonesia. Jakarta: Humanitarian Forum Indonesia \& MDM.

Pahriannoor, Fauzan, A., \& Hadi, Z. (2020). Relationship Of Knowlage And Nurse Attitude With Fire Prevention And Management Of Fire Ar RSUD Ulin Banjarmasin In 2020. Artikel Kesehatan Masyarakat. $p d f$

Thomas, Tracy N., Griffith, Michelle Leander ., Harp, Victoria., Joan P. Cioffi. (2015). Influences of Preparedness Knowledge and Beliefs on Household Disaster Preparedness. 64(35); 965-971

Yulia, F. C. (2020). Kesiapsiagaan Masyarakat Dalam Menghadapi Bencana Kebakaran di Kampung Pelangi Kota Semarang Tahun 2020. Retrived 7 Mei 2021, from http://lib.unnes.ac.id/41191/1/3201416048. 